УДК 323.1

Міщенко Алла Борисівна

https://orcid.org/0000-0001-6693-6221

кандидат політичних наук,

Київський національний університет культури і мистецтв,

Київ, Украӥна,

mishenko.ab@gmail.com

\title{
ДОВІРА ГРОМАДЯН ДО ПОЛІТИКИ ПРАВОГО СПРЯМУВАННЯ В КРАЇНАХ ЄВРОПИ: ІНТЕГРАЦІЙНИЙ АСПЕКТ
}

Зростання ролі та впливовості правих сил в Європі, їх вихід за межі маргінальної підтримки виборців робить актуальною метою дослідження основних тенденцій підвищення рівня довіри громадян до таких політичних партій в країнах Європейського Союзу щодо їх впливу на інтеграційну політику в регіоні. Системності даного аналізу сприяло використання історичного методу при дослідженні джерел, передумов та спільних рис правих сил міжвоєнного періоду та їх сучасного розвитку. Порівняльний метод дозволив визначити тотожні елементи в розумінні понять «праві» та «правий популізм», а також сприяв виявленню розрізнень між правими та лівими політичними партіями Свропи.

Здійснений аналіз довів, що протягом останніх двох десятиліть, праві отримали значний кредит довіри свого ключового електорату, яким став загалом середній клас, сформували загальні гасла щодо заперечення політики Свропейського Союзу в напрямку обмеження міграції, боротьби 3 тероризмом, розподілу квот на прийом біженців, втручання у внутрішні справи держави, що нівелює збереження самобутності етносів та націй. Популізм, євроскептицизм та збільшення представництва у Європарламенті, ставить під загрозу збереження інтеграційної політики, яка була передбачуваною та зрозумілою для усіх учасників об'єднання і безпосередніх країн-партнерів. Україна в даному випадку має працювати над виробленням нової стратегії взаємодії з Європою, враховуючи нові тенденції.

Ключові слова: довіра, нативізм, праві, популізм, інтеграційна політика.

Mishchenko Alla, Candidate of Political Science, Kyiv National University of Culture and Arts, Kyiv, Ukraine aspect

Trust of citizens to right-wing politics in countries of Europe: integration

The role and influence increase of the right forces in Europe, their exit outside marginal support of electors forms the actual aim of the basic tendencies research of the citizens' trust level increase to such political parties in the European Union countries in relation to their influence on integration politics in a region. This analysis consistency was 


\section{ДОВІРА ГРОМАДЯН ДО ПОЛІТИКИ ПРАВОГО СПРЯМУВАННЯ В КРАЇНАХ ЄВРОПИ: ІНТЕГРАЦІЙНИЙ АСПЕКТ}

achieved by using the historical method for sources research, preconditions and general lines of the right forces of interwar period and their modern development. A comparative method allowed to define identical elements in understanding the concepts of "right-wing" and "right-wing populism", as well as assisted to disclosure distinctions between the right and left political parties of Europe.

An accomplished analysis proved that during the last two decades, the right-wing got the considerable credit of trust of the key electorate who became a middle class on the whole, formed general slogans in relation to the denial of politics of European Union in direction of limitation of migration, fight against terrorism, distribution of quotas on the reception of refugees, interference with the internal affairs of the state that levels maintenance of originality of ethnoss and nations. Populism, euroscepticism and increase of representative office in European parliament, puts under a threat maintenance of integration politics that was predictable and clear for all participants of association and direct countriespartners. Ukraine in this case must work on making of new strategy of co-operating with Europe, taking into account new tendencies.

Key words: a trust, nativism, right wing, populism, integration politics.

Мищенко Алла Борисовна, кандидат политических наук, Киевский национальный университет культуры и искусств, Киев, Украина

Доверие граждан к политике правого направления в странах Европы: интеграционный аспект

Возрастание роли и влияния правых сил в Европе, их выход за пределы маргинальной поддержки избирателей делает актуальной целью исследования основных тенденций повышения уровня доверия граждан к таким политическим партиям в странах Европейского Союза относительно их влияния на интеграционную политику в регионе. Системности этому анализу способствовало использование исторического метода при исследовании источников, предпосылок и общих черт правых сил межвоенного периода и их современного развития. Сравнительный метод позволил определить тождественные элементы в понимании понятий «правые» и «правый популизм», а также способствовал выявлению различий между правыми и левыми политическими партиями Европы.

Проведенный анализ показал, что в течение последних двух десятилетий, правые получили значительный кредит доверия своего ключевого электората, которым стал в целом средний класс, сформировали общие лозунги по отрицанию политики Европейского Союза в направлении ограничения миграции, борьбы с терроризмом, распределения квот на прием беженцев, вмешательство во внутренние дела государства, нивелируя сохранение самобытности этносов и наций. Популизм, евроскептицизм и увеличение представительства в Европарламенте, ставит под угрозу сохранение интеграционной политики, которая была предсказуемой и понятной для всех участников объединения и непосредственных 
стран-партнеров. Украина в данном случае должна работать над выработкой новой стратегии взаимодействия с Европой, учитывая новые тенденции.

Ключевые слова: доверие, нативизм, правые, популизм, интеграционная политика.

Постановка проблеми. Остання чверть століття ознаменувалася приходом до влади в багатьох країнах Європи, а потім і США, правих та популістських політичних партій та лідерів. Дана тенденція стала невипадковим актом зневіри громадян у політиках-технократах та євроінтеграторах, а швидше способом відповісти на виклики, які сформувалися в процесі глобалізації та тиску на національні імперативи суспільств.

Відповідно, потребує доведення теза, що довіра громадян до політиків крайнього правого спрямування в країнах ЄС прямо впливає на формування інтеграційних тенденцій в регіоні.

\section{Аналіз останніх досліджень і публікацій.}

Зростанням популярності правих партій в країнах Європи стали об'єктом дослідження ще в період 1970-х років, коли з'явилися перші центри стабільного післявоєнного розвитку у вигляді країн, які досягли суттєвої економічної та політичної стабільності. Це були спроби осягнути спільність між так званими «старими» й «новими» правими щодо спадковості ідеологій та методів діяльності.

Серед зарубіжних вчених, які детально розглядали причини та наслідки підвищення довіри громадян до правих сил та їх наслідки для окремих країнах та регіоні Свропи загалом були Д. Арт (Art, 2006), М. Бурлей (Burleigh, 2018), I. Бурума (Buruma, 2018), Г. Дахс, Д.- Б. Джудіс (Judis, 2016), Г. Кітчельт, Х.-Д. Клінгеманн, Н. Маєр, Л. Марч, М. Мінкенберг, К. Мудде (Mudde, 2007), Н. Урбінаті, Е. Хобсбаум та інші.

Вітчизняна наукова думка в дослідженні правих сил в Європі не надто широка, хоча дослідження в цьому напрямку суттєво розвиваються. Варто згадати про праці вчених В. А. Ачкасова (Achkasov, 2008), М. I. Гримської (Hrymska, 2016), В. Денисюка (Denysiuk, 2016), Ю. Латиша (Latysh, 2016), А. Линецького, В. Литвина (Lytvyn, 2012), А. Полякової (Poliakova, 2012), I. Печеранського (Pecheranskyi, 2018), А. В. Шеховцова (Shekhovtsov, 2008).

Виділення невирішених частин проблеми. Початок XXI ст. відзначився масовим поширенням руху правих сил в Європі та країнах Америки, що в сучасних умовах лише набирає обертів у вигляді підтримки громадян у загальнонаціональному масштабі, вийшовши за рамки локального рівня. Поширення відповідних настроїв серед населення та підвищення рівня їх довіри до політиків такого спрямування відзначається й досить небезпечною риторикою щодо загальнолюдських цінностей, способів міждержавної мирної інтеграції країн, виплеканих й нормативно закріплених в актах (деклараціях, конвенціях) міжнародних інституцій. 


\section{ДОВІРА ГРОМАДЯН ДО ПОЛІТИКИ ПРАВОГО СПРЯМУВАННЯ В КРАЇНАХ ЄВРОПИ: ІНТЕГРАЦІЙНИЙ АСПЕКТ}

Ще більш небезпечним видається загострення ситуації після референдуму у Великобританії щодо виходу країни з СС (т. зв. Брекзит) та подальшої ланцюгової реакції консервативних та сепаратистських рухів в окремих регіонах суверенних держав $€ С$ щодо припинення членства в організації.

Незважаючи на цілу низку комплексних досліджень вузького й широкого спрямування щодо місця й ролі правих сил в Європі, залишається досить невизначеним аспект подальшого наростання тенденцій до підвищення довіри громадян, які можуть призвести до зміни інтеграційної політики Америки та ЄС щодо своїх сусідів. Ще більш актуальним це питання постає 3 точки зору європейської та євроатлантичною інтеграції України, яка була проголошена сучасною владою як пріоритетна стратегія розвитку.

Відповідно, метою дослідження $є$ аналіз тенденцій підвищення рівня довіри громадян до правих сил в країнах ЄС щодо впливу на інтеграційну політику в регіоні.

Головними завданнями статті, відповідно, $є$ визначити особливості застосування понять «праві», «крайні праві», «праві популісти»; виокремити історичні передумови виникнення сучасного руху правих сил та їх спільність 3 фашистськими течіями в Європі XX ст.; дослідити тенденції поширення правих сил та зростання рівня довіри до політиків відповідного спрямування в період 2000-2018 pр. в СС; проаналізувати вплив рівня довіри громадян до правих сил в країнах $Є С$ на формування загальноєвропейської інтеграційної політики.

Виклад основного матеріалу дослідження. За останні майже двадцять років суттєво змінилася внутрішня політика Європи в бік їі правого спрямування. Довіра громадян до політиків, які ратують за збереження культурної самобутності, чистоти нації та консервативного виховання суспільства, стали наріжною риторикою в таких країнах як Австрія, Франція, Нідерланди, Угорщина, Польща й останні голосування в федеративних землях Німеччини.

Ще більш важливим постало питання виникнення загроз щодо інтеграційних процесів спільного проживання в межах Європейського Союзу і щодо механізмів тісної взаємодії з країнами Східної Європи, зокрема з Україною.

Для прикладу, Україна у 2014-2018 pр. стала країною 3 найбільшою фінансовою допомогою від ЄС в розмірі 3,81 мільярда євро, отримала безвізовий режим та наростила обсяги співпраці у впровадженні статей Угоди про асоціацію.

Однак поряд з цим, усі питання реалізації цих форм співпраці наштовхувалися на перешкоди щодо ї доцільності від політиків правого спрямування. Це і референдум в Нідерландах щодо ратифікації Угоди про асоціацію України з СС, результат якого був подоланий голосуванням в Парламенті країни; протистояння у Європарламенті проти макрофінансової допомоги для України, де 124 депутати з 527 проголосували проти цього рішення; також рухи лобістів щодо обмеження квот для українських товарів в доступі на європейські ринки, керуючись лозунгом «Не забирайте роботу в європейців!» та ін. 
Окремо варто згадати про політику уряду Угорщини щодо блокування двосторонньої взаємодії України та НАТО через порушення прав угорців на Закарпатті у зв’язку з прийняттям Закону України «Про освіту» (2017р.). Угорщина наполегливо блокує проведення Комісії Україна-НАТО на рівні глав держав і урядів країн Альянсу - 3 метою вироблення якісних механізмів подальшої співпраці, особливо щодо участі організації в протистоянні незаконним діям Росії в Чорному та Азовському морях та проведенні щорічних військових навчань.

Саме тому основними загрозами для країн, що не є частиною Європейського Союзу в їх інтеграційних намірах є риторика політиків правого спрямування, які за останній період вийшли 3 маргінального й локального рівня на загальнодержавний, чим змінюють підходи в реалізації стратегії зовнішньої політики власних держав й геостратегії європейської політики.

Варто коротко окреслити термінологічні особливості використання в даному дослідженні понять «праві», «крайні праві» та «праві популісти».

$\mathrm{y}$ «Оксфордському політологічному словнику» ми знаходимо наступне тлумачення «правих» - ті, хто в опозиції до соціалізму та соціал-демократії, тяжіють до християнської демократії, націоналізму... а крайні праві - до расизму й фашизму (Concise Oxford Dictionary of Politics, 2006, pp. 545-546).

Праві сили в Європі можуть бути визначені також як популістські, тому що усі вони працюють із єдиним соціальним електоратом та апелюють до одних і тих же лозунгів. Важливими елементами $є$ популістська риторика (неоліберальна економічна політика та партикулярна позиція до соціальних питань); авторитарна етноцентрична (расистська) ідеологія в лозунгах «Франція для французів!», «Польща для поляків!»; пошук винних (турки в Німеччині, араби у Франції й Фландріі), а також в останній період критика неефективного центрального керівництва та «брюсельських бюрократів» (Achkasov, Linetskiy, 2008, p. 9)

Відомий американський вчений Д. Б. Джудіс, визначаючи популістів лівого й правого спрямування пише: «ліві популісти борються за народ проти еліти чи істеблішменту. Це вертикальна політика низів і середнього прошарку, які об'єдналися проти верхівки. Праві популісти борються за народ проти еліти, яку вони звинувачують у потуранні третій стороні, наприклад іммігрантам, ісламістам чи агресивним афроамериканцям» (Judis, 2016, p. 16). Треба обережно ставитися до підвищення довіри громадян до правих популістів сил, адже часто це є ознакою політико-економічною кризи, яка наростає всередині держави або регіону.

Окремо варто відзначити підходи, що визначають передумови виникнення правих сил в сучасному світі. Так, А. Полякова стверджує, що в історичній ретроспективі ми можемо поділити «старі праві» - це фашистські режими міжвоєнної Європи, - та «нові праві», які є чи то спадкоємцями, чи то не досить вдало дистанціюються від лозунгів попередників. Авторка зазначає: «нові праві партії відрізняються від старих правих своєю позицією щодо демократії: «сучасні 


\section{ДОВІРА ГРОМАДЯН ДО ПОЛІТИКИ ПРАВОГО СПРЯМУВАННЯ В КРАЇНАХ ЄВРОПИ: ІНТЕГРАЦІЙНИЙ АСПЕКТ}

праворадикальні партії є антисистемними та критичними до ліберальної демократії, проте не спрямовані проти демократії на словах» (Poliakova, 2012).

Однак цікавою особливістю сучасних правих партій $є$ їх схожість 3 лівим крилом (комуністичними партіями) в риториці щодо «націоналізації ключових галузей промисловості, забезпечені державою права на працю та права на соціальну допомогу, а також підтримка традиційної структури сім’ї» (Poliakova, 2012). Грана різних ідеологічних полях як окремий елемент популізму пов'язаний з електоральною боротьбою партій за прихильність громадян й розширення соціального спектру підтримки.

Відповідно, прямого зв'язку 3 фашистськими політичними режимами міжвоєнного періоду дані партії не мають (лозунги, символіка, поведінкові особливості), а їх риторика грунтується на викликах, які постали перед даними суспільствами в період 3 70-х pp. ХX ст. Але досить цікавим залишається факт, що найбільшої легітимації праві сили здобули саме в країнах, колишнього міжвоєнного домінування фашизму. Так, А. Шеховцов, пояснює: «частина суспільства вважає встановлення колабораціоністських режимів під час Другої світової війни нормальним актом влади, направленим на мінімізацію втрат з боку мирного населення. Крім того, в цих країнах, зазвичай, високо розвинені ревізіоністські суспільно-політичні субкультури, що прагнуть демонізувати комунізм i представити добровільну співпрацю 3 нацистами як природну спробу запобігти встановленню прокомуністичних режимів» (Shekhovtsov, 2008, p. 238).

Але ситуація не $є$ однозначною для усієї Європи. Ті країни, які ще до середини 60-х pp. ХХ ст.володіли власними колоніями в Азії та Африці, більше схильні як до етнічної, так i до релігійної толерантності (Бельгія, Великобританія, Іспанія, Португалія) й підвищення підтримки правих політичних партій всередині держав є незначним. Саме тому вони часто виступають останнім джерелом збереження загальноєвропейських та людських цінностей в ракурсі посягання й на цілісність Свропейського Союзу.

Отже, здійснивши систематизацію різноманітних підходів до виявлення спільних рис правих політичних партій в сучасній Європі, їх можна визначити наступним чином:

- базове обличчя електорату - робітники та середній клас;

- ксенофобська риторика;

- нативізм - жорстке протистояння будь-яким меншинам (іммігрантам, біженцям), яке базується на відчутті належності до певного народу (Hrymska, 2016, p. 13);

- ідея географічної експансії з метою об'єднання нації;

- збереження культури та традицій;

- етнічний націоналізм, що повертає питання суверенітету та кордонів держав на порядок денний інтеграційної політики $€ \mathrm{C}$; 
- ототожнення національного та релігійного націоналізму в країнах, де потужна присутність релігійного чинника в суспільному житті;

- євроскептицизм до спільного проживання й нівелювання діяльності загальноєвропейських інституцій;

- високий рівень безробіття та міграційна політика, але в меншій мірі.

Ключовими представниками правих сил в сучасній Європі, які стали об'єктом дослідження в період 2000-2018 pp., є наступні політичні партії: Партії «Право і справедливість» та «Ліга польських родин» у Польщі; Партії «Велика Румунія» та «Партія румунської національної єдності»; «Австрійська партія свободи»; Угорська партія «Йоббік»; «Національний фронт» у Франції; Болгарський національний союз «Атака»; «Золотий Світанок» у Греції; «Шведські демократи»; «Пегіда» та «Альтернатива для Німеччини» у Німеччині; «Свобода і пряма демократія» у Чехії; «Партії свободи» у Нідерландах; «Ліга Півночі» у Італії.

Аналіз попередніх досліджень та сучасні особливості зростання рівня довіри європейців до політичних партій правого спрямування дали можливість систематизувати ключові тенденції такого процесу, а саме:

- змінилася електоральна база прихильників з бідних і обмежених у правах на середній клас, який прагне здійснити захист уже нарощених можливостей від посягань як держави, так і третьої сторони, якою є іммігранти, тимчасові трудові робітники, представники інших рас і націй;

- ностальгія як «серцевина всіх праворадикальних рухів, а історична пам'ять - їхня ключова категорія» (Latysh, 2016). Як доказ варто згадати ключові тези, на яких грунтувалася пропаганда, що призвела до Брекзиту: відновити втрачені могутність, самобутність, економічну незалежність, право самостійної міграційної та соціальної політики, а також безпекової під тиском загроз тероризму. Політика історичної пам'яті Польщі та Угорщини (особливо щодо України) стала зброєю в руках польських правих політиків. Важливим аспектом цього є якраз не бідність та безробіття населення, а благополуччя націй, які повертають риторику політиків з буденних проблем у відродження історичного антагонізму з іншими народами;

- впровадження пропорційної виборчої системи, яка $\epsilon$ домінуючою в більшості європейських країн, знівелювало й викорінило адресну співпрацю політиків з виборцями. Втрачений зв'язок досить легко відновлюють локальні партії 3 популістською риторикою, що досить якісно співпрацюють з соціальними групами різнонаправленого спрямування й таким чином нарощують прихильність;

- якісним підгрунтям посилення довіри громадян до правих політичних сил стала потужна мережа громадських організацій та рухів, які проводять безперервну роботу щодо популяризації їх ідей. Тут варто згадати антимусульманські протести, рух антиглобалістів, Свропа без мігрантів, мітинги проти біженців та квот на їх розподіл в межах країн ЄС. Загалом, проти політики відкритих дверей, яку відстоюють в Брюсселі. І. Бурума зазначає: «загальною темою у людей, які вірять 


\section{ДОВІРА ГРОМАДЯН ДО ПОЛІТИКИ ПРАВОГО СПРЯМУВАННЯ В КРАЇНАХ ЄВРОПИ: ІНТЕГРАЦІЙНИЙ АСПЕКТ}

в те, що мусульмани загрожують західної цивілізації, $є$ їх відмова визнавати іслам релігійною вірою. Це культура, кажуть вони. I стверджують, що вона не сумісна 3 «західними цінностями». Рівно те ж саме часто говорилося про єврейську «культуру» в минулому» (Buruma, 2018);

- географічне походження правих партій має регіональний характер та локальний рівень представництва. Більшість політичних сил здобули популярність в окремих частинах країни з особливо сильними традиційними поглядами громадян. Часто там, вони навіть складають частину місцевого представницького органу (Бельгія, Іспанія, Німеччина);

- зростання представництва в національних парламентах та урядах й, відповідно, вихід з маргінального стану. В окремих країнах (Греція, Угорщина, Швеція) праві змогли вибороти місця в парламенті, набравши від 3 до 18 \% голосів виборців, що перетворило їх на частину правлячої опозиції або учасників широкої коаліції. У той час як у Австрії, Польщі та Чехії уже сформовані уряди за участі правих, які намагаються визначати як внутрішню, так і зовнішню політику країн. У Франції М. Лепен, яка ратує за вихід з СС та депортацію мігрантів, змогла вийти до 2-го туру президентських виборів, а іiі партія посіла 3-є місце (27,6 \%) на місцевих виборах у 2017 р. Як наслідок, уже сьогодні ми аналізуємо можливе наростання присутності політиків правого спрямування в Європарламенті, що прямо впливає на процеси визначення політики інтеграційного характеру для СС;

- пошук нових перспектив та формування альтернативних до ЄС об’єднань. Мова може йти про відродження активної співпраці в межах Вишеградської четвірки та новостворений союз «Тримор'я», підтриманий США та критикований Німеччиною і Францією. Ця тенденція засвідчує загальне розчарування або навіть несприйняття, особливо в країнах Східної Свропи, якістю розв'язання питань регіональної безпеки під тиском загроз з боку Росії, політики економії (3 \% дефіцит бюджету країни), відсутністю врегулювання процесу масової міграції, втручанням у внутрішні справи держав щодо квот на розподіл біженців, проведення реформ тощо.

Отже, враховуючи загальні тенденції до поширення правих сил в Європі в період 2000-2018 pp., центристським елітам, які намагаються відстоювати загальнолюдські цінності та вироблені повоєнною Свропою пріоритети, варто врахувати посилення позицій політичних сил в найближчому майбутньому. Адже посилення їх ролі та впливовості в одній країні, додає натхнення та стимули на успіх в боротьбі за довіру громадян для політиків відповідного штибу в суміжних країнах регіону.

М. Бурляй пише про необхідність тверезого погляду на дане питання, інакше ми не просто втратимо потенційних союзників, ми втратимо Свропу. Головні загрози, на його думку, криються в тих рішеннях, які поки лише на словах, але можуть стати діями «від торгових війн Трампа до обіцянки Росії та Молдови заблокувати вступ Британії після Брекзиту до Світової організації торгівлі» (Burleigh, 2018). 
Висновки й перспективи подальших досліджень. Отже, суттєве зростання ролі правих політичних партій, особливо підсилених популістськими гаслами, прямо може вплинути на загальні тенденції розвитку всього Європейського Союзу та політики, яку він реалізує щодо своїх сусідів та партнерів. Варто згадати про наростання тенденцій щодо обмеження подальшого розширення ЄС та навіть виходу ключових гравців з даної об'єднання. Приклад успіху цього процесу, який завершиться в 2021 р., підписанням остаточної угоди про вихід Великобританії, відкриє шлях для потенійних правих політиків ратувати за аналогічне майбутнє. Про це уже голосно говорять в Іспаніі, Франції та Греції.

Треба пам'ятати, що політичний спектр Європи змінюється й лише країни, які оголосили про свої євроінтеграційні наміри та зможуть якісно, ефективно та інноваційно «пристосуватися» до нових реалій, отримають відповідний стратегічний результат для власної держави.

Для України виявиться важливим елемент уникнути основних негативних загроз, які щороку будуть лише посилюватися з точки зору зростання прихильності європейців до правих політичних партій. Саме аспект виокремлення ключових механізмів та нестандартних рішень буде основним аспектом в майбутньому науковому дослідженні даної теми.

\section{References:}

1. Achkasov, V., Lineckij, A. (2008). 'Lozhnaja al'ternativa: "tretij put"” evropejskih krajne pravyh' [False Alternative: The "Third Way" of the European Extreme Right]. Politeks [Politeks], no. 1, pp. 5-12.

2. Art, D. (2006) The Politics of the Nazi Past in Germany and Austria. New York: Cambridge University Press.

3. Burleigh, M. (2018) 'Brexit vs. the Irish Question'. Project Syndicate, [online] Available at:< https://www.project-syndicate.org/commentary/brexit-irish-question-ukbreakup-by-michael-burleigh-2018-11> [Accessed 7 November 2018].

4. Buruma, I. (2018) 'The West's Race Problem'. Project Syndicate, [online] Available at:<https://www.project-syndicate.org/commentary/west-race-problem-chemnitzby-ian-buruma-2018-09> [Accessed 13 September 2018].

5. Concise Oxford Dictionary of Politics. (2005). Kyiv: Osnovy.

6. Denysiuk, V. (2016). 'Pravi partii v Yevropi: de zaraz i shcho bude potim?' [Right parties in Europe: where and what will happen next?]. Geostrategy, [online] Available at: <http://geostrategy.ua/news/pravi-partii-v-evropi-de-zaraz-i-so-bude-potim> [Accessed 1 June 2018].

7. Hrymska, M. I. (2016). 'Natyvizm yak skladova ideolohii krainikh pravykh politychnykh partii' [Nativism as a component of the ideology of extreme right-wing political parties]. Hrani [Grani], no. 1, pp. 12-17. 
8. Judis, J. B. (2016) The Populism Explosion: How the Great Recession Transformed American and European Politics. New York: Columbia Global Reports;

9. Kudryk, V. (2017). 'Chas pravykh i vynuvatykh: chy varto Yevropi boiatysia radykalnykh populistiv' [Time is right and guilty: should Europe be afraid of radical populists]. Apostrof, [online] Available at:<https://apostrophe.ua/ua/article/world/europe/2017-01-26/vremya-pravyih-i-vinovatyihnujno-li-evrope-opasatsya-radikalnyih-populistov/9753> [Accessed 26 January 2017].

10. Latysh, Yu. (2016). 'Brekzyt i pravyi povorot u Yevropi' [Brexit and the right turn in Europe]. Krytyka, [online] Available at:〈https://krytyka.com/ua/solutions/opinions/brekzyt-i-pravyy-povorot-u-ievropi> [Accessed 15 June 2016].

11. Lytvyn, V. (2012). 'Populistski partii u strukturi modernykh partiinykh system krain Tsentralnoi Yevropy: porivnialnyi analiz' [Populist parties in the structure of modernist party systems in Central Europe: comparative analysis]. Osvita rehionu : politolohiia, psykholohiia, komunikatsii [The Region Education: Political Science, Psychology, Communication], no. 2, pp. 69-77.

12. Mudde, C. (2007) Populist Radical Right Parties in Europe. Cambridge: Cambridge University Press.

13. Pecheranskyi, I. (2018). 'Pravovyi ideolohichnyi rukh Yevropy ta politychni uroky dlia Ukrainy' [The legal ideological movement of Europe and political lessons for Ukraine. Mizhnarodni vidnosyny: teoretyko-praktychni aspekty [International Relations: Theory and Practical Aspects], Vol. 1, pp.63-72. DOI: https://doi.org/10.31866/2616745x.1.2018.133414.

14. Poliakova, A. (2012).'Pravoradykalni partii v Tsentralno-Skhidnii Yevropi: tse ekonomika?' [Right radical parties in Central and Eastern Europe: is it an economy?]. Spilne: zhurnal sotsialnoi krytyky [Commons: Journal of Social Criticism], no. 5, pp. 39-52.

15. Shekhovtsov, A. V. (2008). "Osoblyvosti politychnoi kultury i elektoralna pidtrymka novykh pravoradykalnykh partii v yevropeiskykh krainakh' [Features of political culture and electoral support of new right-wing radical parties in European countries ]. Politolohichnyi visnyk [Political Science Herald], no. 37, pp. 237-246.

(С) Міщенко А. Б., 2019 